\section{Vesna Matić}

Udruženje banaka Srbije vesna.matic@ubs-asb.com

\section{Bankarski rizik 53}

\section{ANA \\ KREDIT}

\title{
Rezime
}

Da bi obezbedila dobru podršku realizaciji nekih svojih zadataka u evro sistemu u oblasti supervizije stabilnosti finansijskih sistema, upravljanja rizicima i vođenja monetarne politike, Evropska centralna banaka usvojila je projekat osnivanja obuhvatne baze podataka sa detaljnim informacijama o kreditima pojedinačnih banaka u evro zoni pod nazivom Ana Credit. Puna realizacija projekta počinje 30. septembra 2018.

Ključne reči: ECB, baza podataka, podaci o kreditima, kreditni registar

JEL: F36, G21 


\section{Banking Risk 53}

Vesna Matić

Association of Serbian Banks vesna.matic@ubs-asb.com

\section{ANA \\ CREDIT}

\section{Summary}

To support the implementation of some tasks in the Euro system regarding the financial system stability supervision, risk management and monetary policy, the European Central Bank adopted a project of setting up a comprehensive database containing the detailed information on individual bank loans in the Eurozone, named Ana Credit. The full implementation of the project begins on 30 September 2018.

Key words: ECB, dataset, credit data, credit register

JEL: F36, G21 
Evropska centralna banka (ECB) prezentovala je 2014. pravac budućeg razvoja mikro i makro prudencine supervizije $u$ evro sistemu koji bazira na projektu osnivanja obuhvatne baze podataka sa detaljnim informacijama o kreditima pojedinačnih banaka u evro zoni, harmonizovanim preko svih država članica. Ova analitička baza podataka o kreditima poznata je pod nazivom Ana Credit.

Projekat je iniciran 2011. a prikupljanje podataka bi trebalo da počne u septembru 2018. Cilj ECB je da osnuje centralni kreditni registar za sve države članice evro zone do kraja 2018. (inicijalni plan bio je 2016). One su obavezne da učestvuju, dok su zemlje članice Evropske unije koje nisu u evro sistemu pozvane da učestvuju na dobrovoljnoj osnovi. Pojedinačni podaci o kreditima trebalo bi da pomognu prikupljanje podataka o kreditima i kreditnim rizicima kreditnih institucija lociranih $\mathrm{u}$ evro zoni, stranih filijala kreditnih institucija u evrozoni, uključujući i one koje nisu rezidenti u evro zoni i stranih filijala lociranih u evro zoni koje nisu deo kreditnih institucija van evro zone.

Uz odgovarajuća statistička rešenja ova baza bi trebalo da podrži zadatke ECB-a u evro sistemu u oblasti uspešnije primene banakarske supervizije i stabilnosti finansijskog sistema, $\mathrm{u}$ oblasti supervizije finansijske stabilnosti, $\mathrm{u}$ upravljanju rizicima, $\mathrm{u}$ izradi monetarnih analiza i vođenju monetarne politike.

\section{Regulatorni okvir i realizacija projekta}

Nacrt regulatornog okvira za realizaciju projekta Ana Credit i formiranje centralnog kreditnog registra urađen je $\mathrm{u}$ novembru 2015. a konačnu verziju regulative usvojio je Upravljački savet ECB 18. maja 2016.

ECB je definisala proces i faze $u$ procesu kojim će razviti kreditni registar u evro sistemu. Projekat će se realizovati u Nemačkoj preko široke skale izveštaja o kreditima do 2018. godine. Od nacionalnih centralnih banaka će se zahtevati da pošalju ECB test izveštaje šest meseci pre prvog kompletnog izveštavanja 30. septembra 2018. Nacionalne centralne banke mogu uvesti izveštavanje u ranijim rokovima, ali prvi izveštaji ne bi trebalo da budu bazirani na izveštajnom datumu pre 31. decembra 2017.

Izveštajne šeme pokazuju da će institucije morati da razmotre veliki broj kreditnih podataka na nivou pojedinačnog kredita prilikom izrade izveštaja za kreditni registar. Od institucija se može zahtevati da razmotre i dodatne podatke i kompletiraju izveštaje, kako bi se dostigao zahtevani nivo granulacije. Osim toga, nizak donji prag izveštavanja potvrđuje rastući broj dužnika i kredita koji su već obuhvaćeni i koji će biti obuhvaćeni u narednom periodu.

\section{Literatura / References}

1. Finance \& Risk, Banking HUB by zeb, Update: Analitical credit data set of the ECB Ana Credit Further developing, June 2016. 
In 2014 the European Central Bank (ECB) presented a roadmap for the further development of the micro and macro prudential supervision in the Euro system based on the project of setting up a comprehensive database containing the detailed information on individual bank loans in the Euro area, harmonized across all member states. This analytical credit database is known as Ana Credit.

The project was initiated in 2011 and the data collection is scheduled to start on 30 September 2018. The ECB aims to establish a central credit register for all member states in the Euro area by the end of 2018 (the initial plan was 2016). They are obliged to participate, while the member states of the European Union outside the Euro system are invited to participate on a voluntary basis. The granular credit data should support the collection of data about loans and credit risks of credit institutions located in the Euro area, foreign branches of the Euro area credit institutions including those that are not resident in the Euro area and foreign branches located in the Euro area that are part of credit institutions outside the Euro area.

With the relevant statistics this database is supposed to support the ECB tasks in the Euro system regarding a smoother implementation of banking supervision and financial system stability, in the field of financial stability supervision, risk management, preparation of monetary analyses and conducting of monetary policy.

\section{Regulatory Framework and Project Implementation}

The draft regulatory framework for the implementation of Ana Credit Project and the formation of the central credit register was launched in November 2015, and the final regulations were adopted by the ECB's Governing Council on 18 May 2016.

The ECB developed a roadmap of how to develop the credit register in the Euro system. The project will be implemented in Germany in the form of large scale loan reporting by 2018. The national central banks are required to submit their test reports to the ECB six months prior to the first complete reporting on 30 September 2018. The national central banks may introduce this form of reporting in an earlier stage, but the first reports should not be based on the reporting date prior to 31 December 2017.

The reporting shames show that the institutions will have to examine a large amount of granular credit data at the level of individual loans for the purpose of their reports to the credit register. Institutions may be required to collect additional data to fulfill the reporting requirements and meet the required granular level. The low threshold of reporting also confirms the increasing number of borrowers that are currently covered and that will be covered in the forthcoming period. 